\title{
Host defence peptides identified in human apolipoprotein B as promising antifungal agents
}

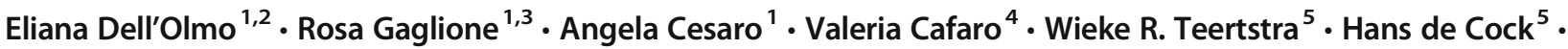 \\ Eugenio Notomista ${ }^{4} \cdot$ Henk P. Haagsman $^{2} \cdot$ Edwin J. A. Veldhuizen ${ }^{2} \cdot$ Angela Arciello $^{1,3}$ (I)
}

Received: 9 July 2020 / Revised: 4 December 2020 / Accepted: 13 January 2021 / Published online: 12 February 2021

(C) The Author(s) 2021

\begin{abstract}
Therapeutic options to treat invasive fungal infections are still limited. This makes the development of novel antifungal agents highly desirable. Naturally occurring antifungal peptides represent valid candidates, since they are not harmful for human cells and are endowed with a wide range of activities and their mechanism of action is different from that of conventional antifungal drugs. Here, we characterized for the first time the antifungal properties of novel peptides identified in human apolipoprotein $\mathrm{B}$. ApoB-derived peptides, here named $r(\mathrm{P}) \mathrm{ApoB}_{\mathrm{L}}{ }^{\text {Pro }}, \mathrm{r}(\mathrm{P}) \mathrm{ApoB}_{\mathrm{L}}{ }^{\text {Ala }}$ and $\mathrm{r}(\mathrm{P}) \mathrm{ApoB}_{\mathrm{S}}{ }^{\text {Pro }}$, were found to have significant fungicidal activity towards Candida albicans (C. albicans) cells. Peptides were also found to be able to slow down metabolic activity of Aspergillus niger (A. niger) spores. In addition, experiments were carried out to clarify the mechanism of fungicidal activity of ApoB-derived peptides. Peptides immediately interacted with C. albicans cell surfaces, as indicated by fluorescence live cell imaging analyses, and induced severe membrane damage, as indicated by propidium iodide uptake induced upon treatment of C. albicans cells with ApoB-derived peptides. ApoB-derived peptides were also tested on A. niger swollen spores, initial hyphae and branched mycelium. The effects of peptides were found to be more severe on swollen spores and initial hyphae compared to mycelium. Fluorescence live cell imaging analyses confirmed peptide internalization into swollen spores with a consequent accumulation into hyphae. Altogether, these findings open interesting perspectives to the application of ApoB-derived peptides as effective antifungal agents.
\end{abstract}

\section{Key points}

- Human cryptides identified in ApoB are effective antifungal agents.

- ApoB-derived cryptides exert fungicidal effects towards C. albicans cells.

- ApoB-derived cryptides affect different stages of growth of A. niger.

Keywords Antifungal peptides $\cdot$ Human cryptides $\cdot$ Fungal infections $\cdot$ Peptide therapeutics

\section{Introduction}

The emergence of fungal infections represents a worldwide issue with a serious economic and social impact (Ciociola et al. 2016). Since the 1980s, an increase in cases of serious

Edwin J. A. Veldhuizen

e.j.a.veldhuizen@uu.nl

$\triangle$ Angela Arciello

anarciel@unina.it

1 Department of Chemical Sciences, University of Naples Federico II, 80126 Naples, Italy invasive fungal infections is observed due to the growing number of highly susceptible people, mainly immunocompromised, elderly and transplanted subjects, cancer patients and premature infants (Brown et al. 2012). Fungal pathogens as Candida, Aspergillus, Pneumocystis, and Cryptococcus spp.

2 Department of Biomolecular Health Sciences, Division of Infectious Diseases and Immunology, Section Molecular Host Defence, Faculty of Veterinary Medicine, Utrecht University, Utrecht, The Netherlands

3 Istituto Nazionale di Biostrutture e Biosistemi (INBB), Rome, Italy

4 Department of Biology, University of Naples Federico II, 80126 Naples, Italy

5 Molecular Microbiology, Department of Biology, Faculty of Science, Utrecht University, Utrecht, The Netherlands 
are responsible for 1.4 million deaths each year (Brown et al. 2012; Sanglard 2016). The situation is even more complicated because of the variety and non-specificity of symptoms (Schmiedel and Zimmerli 2016), ranging from either mild and superficial (e.g. cutaneous infections as dermatophytosis and tinea versicolor) to life-threatening, systemic illness (e.g. candidiasis, aspergillosis and mucomycosis).

\section{Infections by Candida and Aspergillus species}

Although C. albicans is a normal commensal for humans (Hancock and Lehrer 1998; Bennett et al. 2014), it is responsible for $75 \%$ of women vaginal candidiasis and for $90 \%$ of oropharyngeal candidiasis in HIV-infected patients with AIDS (Staab 1999; Sobel 2007). Indeed, C. albicans has been found to be able to invade a local site (mucocutaneous or cutaneous candidiasis, onychomycosis) or to cause systemic infections (renal, liver abscess, lung and nervous central system) (Badiee and Hashemizadeh 2014). It has also been reported that Candida species are the most common pathogens responsible for infections in hospitalized patients characterized by a high mortality rate (Strollo et al. 2017). Among fungal species able to colonize humans, Aspergillus spp. have been reported to be responsible for several types of infections and allergic bronchopulmonary aspergillosis (Anaissie et al. 2002; Alastruey-Izquierdo et al. 2013; Badiee and Hashemizadeh 2014). Indeed, Aspergillus ubiquitous spores are able to reach the respiratory tract by inhalation, thus causing noninvasive and invasive pulmonary aspergillosis, the latter especially in immunocompromised hosts. Along with the difficulties in the diagnosis, the narrow spectrum of available antifungals leads to the rapid rise of resistance phenotypes (Cowen et al. 2015; Fisher et al. 2018a). Indeed, the therapeutic options for invasive fungal infections are limited to only three structural classes of drugs, such as polyenes, azoles and echinocandins (Morita and Nozawa 1985; Roemer and Krysan 2014). Polyenes, including amphotericin B, exert significant toxic effects that might be overcome by developing awfully expensive formulations. For these reasons, the most tolerated azoles or echinocandins are the preferred therapeutic option (Bellmann and Smuszkiewicz 2017). Examples are represented by fluconazole to treat Candida infections or voriconazole to treat aspergillosis. Echinocandins are effective against several fungal strains, such as Candida spp., including no-albicans strains, and have been reported to exert fungistatic effects on Aspergillus spp. (Bowman et al. 2002; Bellmann and Smuszkiewicz 2017). Unfortunately, many cases of resistant fungal strains have been reported, due to the lower number of antifungal drugs available and to delays in diagnosis (Cowen et al. 2015; Fisher et al. 2018b). Hence, the discovery and development of novel alternative strategies is imperative.

\section{Host defence peptides as antifungal peptides}

Host defence peptides (HDPs), which comprise antifungal peptides (AFPs), may represent valid candidates (Sun et al. 2018; Mookherjee et al. 2020) (Zasloff 2002; Thevissen et al. 2007; Lupetti et al. 2008) because of their unique properties, such as their selectivity towards bacterial/fungal cells, their mechanism of action, which is different from that of conventional antifungal drugs and their moderate toxicity and immunogenicity (Lupetti et al. 2008; Aoki and Ueda 2013; Ciociola et al. 2016). Antifungal peptides represent a group of evolutionarily conserved molecules of the innate immune system present in all complex living organisms. They are characterized by common features, such as small size, positive net charge and high hydrophobicity (Thery et al. 2019a). Based on their mechanism of action, they can be classified into (i) membrane traversing peptides, which are able to lead membrane pore formation or to act on specific targets, such as $\beta$ glucan or chitin synthesis; and (ii) non-membrane traversing peptides, which interact with cell membrane and consequently cause cell lysis (Neelabh et al. 2016). Nowadays, more than 1200 antifungal peptides isolated from bacteria, other fungi, plants and animals have been identified and listed in databases (Essig et al. 2014; Thery et al. 2019a). Mammalian organisms release a large amount of AFPs as components of the innate immune system. Examples are $\alpha$ - and $\beta$-defensins, cathelicidins and histatins (Kościuczuk et al. 2012; Cuperus et al. 2013; Bondaryk et al. 2017), which have been found to be effective towards a wide range of fungal pathogens (Mookherjee et al. 2020), including C. albicans and Aspergillus spp.

\section{ApoB-derived peptides as antifungal peptides}

Here, we analysed for the first time the antifungal properties of three recombinant peptides identified in human apolipoprotein B (Gaglione et al. 2017; Gaglione et al. 2019b; Gaglione et al. 2019a), here named $r(P) A_{\text {poB }}{ }_{L}^{\text {Pro }}, r(P) A_{\text {poB }}{ }^{\text {Ala }}$ and $\mathrm{r}(\mathrm{P}) \mathrm{ApoB}_{\mathrm{S}}{ }^{\text {Pro }}$, where $(\mathrm{P})$ indicates the presence of an additional Pro residue at the N-terminus of the peptides released by the acidic cleavage of an Asp-Pro bond; superscripts "Pro" and "Ala" stand for the amino acid residue at position 7 (Gaglione et al. 2020), whereas subscripts " $L$ " and "S" indicate a longer and a shorter version of the identified peptide, respectively (Gaglione et al. 2017; Gaglione et al. 2020). Peptides' sequences, lengths, isoelectric points, experimental and theoretical molecular weights and net charges at neutral $\mathrm{pH}$ are reported in Table 1. In the present study, we found that ApoB-derived peptides exert significant fungicidal effects towards $C$. albicans cells by affecting membrane permeability. ApoB-derived peptides have been found to inhibit $A$. niger filamentous fungus strongly also. Indeed, peptides were demonstrated to slow down the metabolic activity of $A$. niger spores, hyphae and 


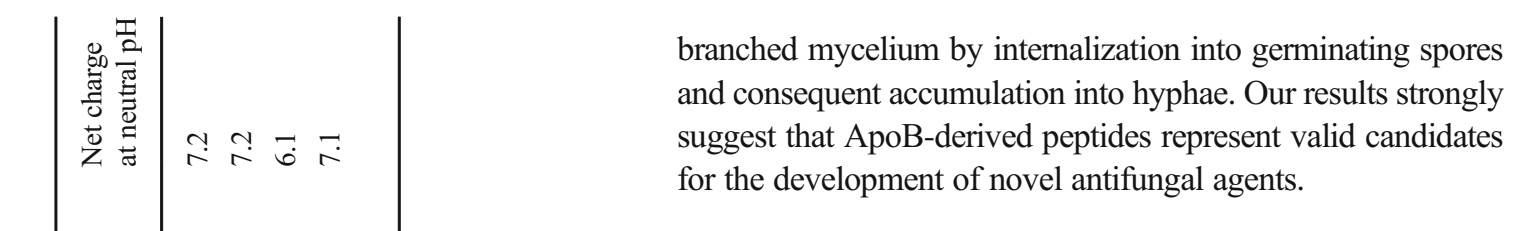

Materials and methods

\section{Materials}

All reagents were purchased from Merck (Milan, Italy), unless specified otherwise. CATH-2 peptide was obtained from CPC Scientific Inc. (Sunnyvale, USA).

\section{Fungal strains and growth conditions}

Cultures of C. albicans ATCC 10231 were grown on Yeast Malt (YM) agar plates. For all the experiments, yeasts were cultured at $30^{\circ} \mathrm{C}$ in $10 \mathrm{~mL}$ yeast extract peptone dextrose broth (YPD) until mid-logarithmic phase was reached. Growth rate was monitored by measuring optical density (OD) values at 620 $\mathrm{nm}$; when mid-logarithmic phase was reached, Candida cells were collected and diluted to $2 \times 10^{6} \mathrm{CFU} / \mathrm{mL}$ in $1 / 100 \mathrm{YM}$ broth. To determine minimal fungicidal concentration (MFC) values, tenfold dilutions of culture were plated into $\mathrm{YM}$ broth. A. niger $\mathrm{N} 402$ was grown at $30^{\circ} \mathrm{C}$ in $20-\mathrm{mL}$ minimal medium (MM) (De Vries et al. 2004) containing 2\% glucose and 1.5\% agar. Conidia used to inoculate cultures were harvested from 4day-old colonies by using a solution containing $0.8 \% \mathrm{NaCl}$ and $0.005 \%$ Tween- 80 .

\section{Expression ad isolation of recombinant ApoB-derived peptides}

Expression and isolation of recombinant peptides were performed as described previously (Gaglione et al. 2017; Pane et al. 2018b; Gaglione et al. 2019b; Gaglione et al. 2020). ApoB-derived peptides' sequences are reported in Table 1.

\section{Production of fluorescently labelled $r(C) A p o B_{L}{ }^{\text {Pro }}$}

$\mathrm{r}(\mathrm{C}) \mathrm{ApoB}_{\mathrm{L}}{ }^{\text {Pro }}$ was obtained by chemical hydrolysis of purified ONC-DCless-H6-(C)-ApoB ${ }_{\mathrm{L}}{ }^{\text {Pro }}$ fusion protein in $5 \mathrm{M}$ guanidine- $\mathrm{HCl}$ containing $1 \mathrm{mM}$ TCEP (tris(2carboxyethyl)phosphine) at $\mathrm{pH}$ 7.4. A chimeric construct was expressed and purified as previously reported (Gaglione et al. 2017; Pane et al. 2018b; Gaglione et al. 2019b; Gaglione et al. 2020). Peptide release was monitored by reversed-phase high-performance liquid chromatography (RP-HPLC) carried out by using a Jasco LC-4000 system equipped with PU-4086 semipreparative pumps and MD-4010 photo diode array detector. A Europa Protein $300 \mathrm{C} 18$ column $(5 \mu \mathrm{m}, 25 \times 1)$ from Teknokroma (Barcelona, Spain) was used. Solvents were 
$0.05 \%$ trifluoroacetic acid (TFA) in water (solvent A) and $0.05 \%$ TFA in acetonitrile (solvent B). Elution profiles were recorded by a linear gradient as follows: from 5 to $25 \%$ solvent $\mathrm{B}$ in $10 \mathrm{~min}$, from 25 to $35 \%$ solvent $\mathrm{B}$ in $30 \mathrm{~min}$, from 35 to $50 \%$ solvent B in $10 \mathrm{~min}$, from 50 to $100 \%$ solvent B in $10 \mathrm{~min}$, and isocratic elution at $100 \%$ solvent $\mathrm{B}$ for $10 \mathrm{~min}$. Elution was monitored at $214 \mathrm{~nm}$ at a flow rate of $2 \mathrm{~mL} / \mathrm{min}$. $\mathrm{r}(\mathrm{C}) \mathrm{ApoB}_{\mathrm{L}}{ }^{\text {Pro }}$ peptide was then purified by a column-free procedure based on different solubilities of carrier and peptide at pH 7.0 (Pane et al. 2018b). To this purpose, the hydrolysis mixture was neutralized by adding a diluted ammonia solution for $5 \mathrm{~min}$ at $28{ }^{\circ} \mathrm{C}$ under nitrogen atmosphere. Insoluble fusion protein and carrier were then separated from soluble peptide by 10 -min centrifugation at $18,000 \mathrm{~g}$ at $4{ }^{\circ} \mathrm{C}$. The soluble fraction was analysed by RP-HPLC performed by using a Europa Protein 300 C18 column (Teknokroma, Barcelona, Spain) as previously described, in order to evaluate peptide purity. Supernatant, containing soluble peptide, was subjected to the labelling reaction.

\section{Labelling of purified peptide}

$\mathrm{r}(\mathrm{C}) \mathrm{ApoB}_{\mathrm{L}}{ }^{\text {Pro }} \mathrm{N}$-terminal cysteine reactive residue was labelled with the thiol-reactive probe 5iodoacetamidofluorescein (5'-IAF), in order to produce 5'IAF-r(C)ApoB ${ }_{L}{ }^{\text {Pro }}$ labelled peptide. Purified $r(C) A_{p o B}{ }_{L}{ }^{\text {Pro }}$ peptide $(9.6 \mathrm{mg}, 60 \mu \mathrm{M}$ final concentration) was incubated with 5'-IAF ( $0.25 \mathrm{mM}$ final concentration; $15 \mathrm{mM}$ stock solution in dimethyl formamide) in $15 \mathrm{mM}$ sodium phosphate buffer (NaP) pH 7.4 containing $2 \mathrm{M}$ guanidine- $\mathrm{HCl}$ for $2 \mathrm{~h}$ at $25{ }^{\circ} \mathrm{C}$ in the dark under nitrogen atmosphere. Molar ratio of 5'-IAF over thiols was 4:1. $\mathrm{r}(\mathrm{C}) \mathrm{ApoB}_{\mathrm{L}}{ }^{\text {Pro }}$ labelling reaction was monitored by RP-HPLC performed on a Europa Protein $300 \mathrm{C} 18$ column as reported above (Figure S2). To simplify peptide purification by RP-HPLC, the reaction was quenched by adding L-cysteine in a molar excess of 10:1 on 5'-IAF for $1 \mathrm{~h}$ at $37^{\circ} \mathrm{C}$ in the dark. 5 'IAF-r(C)ApoB ${ }_{\mathrm{L}}{ }^{\text {Pro }}$ was purified by RP-HPLC and lyophilized and resuspended in water. Labelled peptide concentration was determined using the molar extinction coefficient reported in the literature (5'-IAF $\varepsilon 492 \mathrm{~nm}=$ $80,000-85,000 \mathrm{M}^{-1} \mathrm{~cm}^{-1}$ ) and by BCA colorimetric assay. Purity of labelled peptide was evaluated by RP-HPLC performed on Europa Protein 300 C18 column.

\section{Determination of minimal fungicidal concentration values}

MFC (minimum fungicidal concentration) values were assessed by colony counting assays, as previously described (Van Dijk et al. 2007), with few modifications. Briefly, $50 \mu \mathrm{L}$ of a $2 \times 10^{6} \mathrm{CFU} / \mathrm{mL}$ suspension of $C$. albicans ATCC 10231 cells in $1 / 100 \mathrm{YM}$ broth were incubated for $3 \mathrm{~h}$ at $37^{\circ} \mathrm{C}$ with an equal volume of peptide $(0-40 \mu \mathrm{M})$. Tenfold dilutions in
YM broth were then plated onto YPD agar plates and incubated overnight at $37^{\circ} \mathrm{C}$. Finally, colonies of surviving yeast cells were counted.

\section{Killing kinetic studies}

To kinetically analyse fungicidal activity of ApoB-derived peptides, experiments on C. albicans ATCC 10231 cells were performed. Yeast cells grown overnight in YM (Yeast Malt) medium were diluted in fresh YM medium and then incubated at $37{ }^{\circ} \mathrm{C}$ until logarithmic phase of growth was reached. Yeasts were then diluted to $2 \times 10^{6} \mathrm{CFU} / \mathrm{mL}$ in a final volume of $500 \mu \mathrm{L}$ in $1 / 100 \mathrm{YM}$ broth and mixed with the peptides $(1: 1 \mathrm{v} / \mathrm{v})$. Increasing concentrations of peptide were analysed (ranging from 0 to $20 \mu \mathrm{M}$ ). At defined time intervals, samples $(20 \mu \mathrm{L})$ were serially diluted (from 10 - to 10,000 -fold), and $100 \mu \mathrm{L}$ of each dilution was plated on YPD Agar. Following an incubation of $16 \mathrm{~h}$ at $37^{\circ} \mathrm{C}$, yeast colonies were counted.

\section{PI uptake assay}

Propidium iodide uptake was monitored as previously described (Stone et al. 2003) with some modifications. Briefly, $45 \mu \mathrm{L}$ of $1 \times 10^{7} \mathrm{CFU} / \mathrm{mL}$ of C. albicans ATCC 10231 cells were plated into 96-well plates, treated with $45 \mu \mathrm{L}$ of peptides with increasing concentrations $(0-20 \mu \mathrm{M})$ and incubated for $1 \mathrm{~h}$ at $37{ }^{\circ} \mathrm{C}$. After that, $10 \mu \mathrm{L}$ of PI at a final concentration of $5 \mu \mathrm{M}$ was added. After $10 \mathrm{~min}$ of incubation, PI fluorescence was measured by using a microtiter plate reader (FLUOstar Omega, BMG LABTECH, Germany) at an excitation wavelength of $485 \mathrm{~nm}$ and an emission wavelength of $650 \mathrm{~nm}$. The percentage of PI uptake was calculated as follows: [F(sample)-F(CTRL)/ $\mathrm{F}(100 \%)-\mathrm{F}(\mathrm{CTRL})] \times 100$, where $\mathrm{F}(\mathrm{CTRL})$ is the fluorescence of untreated sample and $\mathrm{F}(100 \%)$ is the fluorescence of heat-treated samples $\left(15 \mathrm{~min}\right.$ at $\left.95{ }^{\circ} \mathrm{C}\right)$.

\section{ATP release assay}

ATP released by cells exposed to peptides was measured by using an ATP determination kit from Molecular Probes (Life Sciences, Bleiswijk, The Netherlands). Briefly, a suspension of $1 \times 10^{7} \mathrm{CFU} / \mathrm{mL}$ C. albicans ATCC 10231 cells in 1:100 YM was incubated with increasing concentrations of each peptide for 10 and $60 \mathrm{~min}$ at $37{ }^{\circ} \mathrm{C}$. Samples were then centrifuged for $1 \mathrm{~min}$ at $1200 \times \mathrm{g}$ and the supernatant was stored on ice for ATP determination, performed as described by the manufacturer. ATP concentration in control samples was found to be lower than $10 \mathrm{nM}$ (data not shown). 


\section{Localization of $5^{\prime}$-IAF-r(C)ApoB ${ }_{\mathrm{L}}{ }^{\text {Pro }}$ by confocal laser scanning live imaging microscopy}

Experiments were performed as previously described by Jang and co-workers with some modifications (Jang et al. 2010). For all the experiments, 35-mm culture dishes (FluoroDish ${ }^{\mathrm{TM}}$, WPI, Sarasota, FL) were coated with $0.5 \mathrm{mg} / \mathrm{mL}$ Concanavalin A in water. A suspension $(100 \mu \mathrm{L})$ of $1 \times 10^{7}$ $\mathrm{CFU} / \mathrm{mL}$ C. albicans ATCC 10231 in 1:100 YM medium was then added. Fluorescently labelled peptide $(50 \mu \mathrm{L})$ was added in the medium containing $5 \mu \mathrm{M}$ PI. In the case of A. niger N402 hyphae, $100 \mu \mathrm{L}$ of a solution of $1 \times 10^{7}$ spores $/ \mathrm{mL}$ were incubated at $37{ }^{\circ} \mathrm{C}$ for $24 \mathrm{~h}$ in the presence of peptides. At defined time points $(0,16$ and $24 \mathrm{~h})$, analyses were performed. Images were acquired by using a Leica SPE-II and a $63 \times$ objective at the Centre for Cell Imaging (CCI) - Utrecht University. A 488-nm argon laser and a 561-nm DPSS laser were used for simultaneous detection of 5'-IAF-r(C)ApoB ${ }_{\mathrm{L}}{ }^{\text {Pro }}$ and PI, respectively.

\section{Metabolic activity analyses}

The effects of ApoB-derived peptides on A. niger N402 metabolic activity were analysed by using cell proliferator reagent WST-1 (Roche Applied Science, Mannheim, Germany). Briefly, $45 \mu \mathrm{L}$ of a $1 \times 10^{5}$ spores $/ \mathrm{mL}$ suspension in MM were incubated for $24 \mathrm{~h}$ at $30{ }^{\circ} \mathrm{C}$ with an equal volume of peptide $(0-40 \mu \mathrm{M})$. In each well, $10 \mu \mathrm{L}$ of WST-1 $10 \times$ were added. At defined time intervals, sample absorbance values were measured at $450 \mathrm{~nm}$ by using $650 \mathrm{~nm}$ as reference wavelength at a microtiter plate reader (FLUOstar Omega, BMG LABTECH, Germany). To investigate the effects of ApoBderived peptides on A. niger N402 swollen spores, hyphae, and mycelium, these were incubated in MM containing 2\% glucose for 6,16 and $24 \mathrm{~h}$ prior to treatment with peptides, respectively.

\section{Statistical analyses}

Statistical analysis was performed using ANOVA or Student's $t$ test. Significant differences were indicated as $*(P<0.05)$, $* *(P<0.01), * * *(P<0.001)$ or $* * * *(P<0.0001)$.

\section{Results}

\section{Antifungal activity of $r(P) A_{p o B} B_{L}^{\text {Pro }}, r(P) A_{p o B_{s}}{ }^{\text {Pro }}$ and $r(P)$ Apo ${ }_{L}{ }^{\text {Ala }}$ peptides}

The antifungal properties of recombinant ApoB-derived peptides were tested. First of all, we evaluated purity and integrity of the peptides by performing SDS-PAGE and mass spectrometry analyses, as shown in Supplementary Figures S1 and S2. We firstly investigated the effects of peptides on C. albicans ATCC 10231. For this purpose, increasing amounts of $r(\mathrm{P}) \mathrm{ApoB}_{\mathrm{L}}{ }^{\text {Pro }}, \mathrm{r}(\mathrm{P}) \mathrm{ApoB}_{\mathrm{S}}{ }^{\text {Pro }}$ or $\mathrm{r}(\mathrm{P}) \mathrm{ApoB}_{\mathrm{L}}{ }^{\text {Ala }}$ were incubated with the fungal cells for $3 \mathrm{~h}$ and the chicken CATH-2 peptide was used as positive control. As shown in Fig. 1, ApoB-derived peptides were found to exert a strong fungicidal activity towards C. albicans ATCC 10231 at $10 \mu \mathrm{M}$ of $\mathrm{r}(\mathrm{P}) \mathrm{ApoB}_{\mathrm{L}}{ }^{\text {Pro }}$ and $\mathrm{r}(\mathrm{P}) \mathrm{ApoB}_{\mathrm{L}}{ }^{\mathrm{Ala}}$ and at $20 \mu \mathrm{M}$ for the shorter version of the peptide. $\mathrm{MFC}_{100}$ (minimal fungicidal concentrations) values determined when peptides were tested on C. albicans ATCC 10231 are reported in Supplementary Table S1.

In order to analyse the antifungal effects of ApoB-derived HDPs over time, kinetic killing curves were obtained by treating C. albicans ATCC 10231 with increasing concentrations of each peptide and for different time intervals. At the highest peptide concentrations tested $(5-10 \mu \mathrm{M}), C$. albicans ATCC 10231 was killed within $10 \mathrm{~min}$, whereas, at lower concentrations $(5 \mu \mathrm{M})$, the same effects were observed after 180 min (Fig. 2).

\section{Effects of ApoB-derived peptides on yeast cell membranes}

In order to determine the mechanism of fungicidal activity of ApoB-derived HDPs, propidium iodide uptake was analysed upon treatment of C. albicans ATCC 10231 cells with peptides. C. albicans ATCC 10231 cells were treated with ApoBderived peptides at concentrations corresponding to MFC values for $1 \mathrm{~h}$ at $37^{\circ} \mathrm{C}$. A significant increase of propidium iodide uptake was selectively observed in the case of cells treated with ApoB-derived peptides (Fig. 3). This clearly suggests that ApoB-derived peptides' antifungal activity against

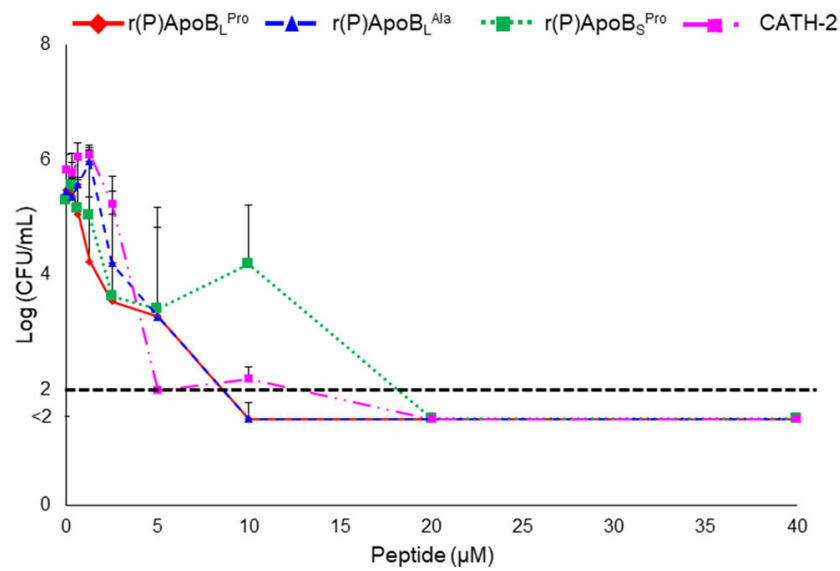

Fig. 1 Antifungal activity of $r(\mathrm{P}) \mathrm{ApoB}_{\mathrm{L}}{ }^{\text {Pro }}, \mathrm{r}(\mathrm{P}) \mathrm{ApoB}_{\mathrm{L}}{ }^{\mathrm{Ala}}$ and $\mathrm{r}(\mathrm{P}) \mathrm{ApoB}_{\mathrm{S}}{ }^{\mathrm{Pro}}$ peptides. Minimum fungicidal concentration (MFC) values were assessed by colony count assays. Data represent the mean $( \pm$ SEM) of three independent experiments, each one carried out with triplicate determinations. CATH-2 peptide was used as a positive control. Point values below the black dashed line represent conditions in which 0 colonies were counted 

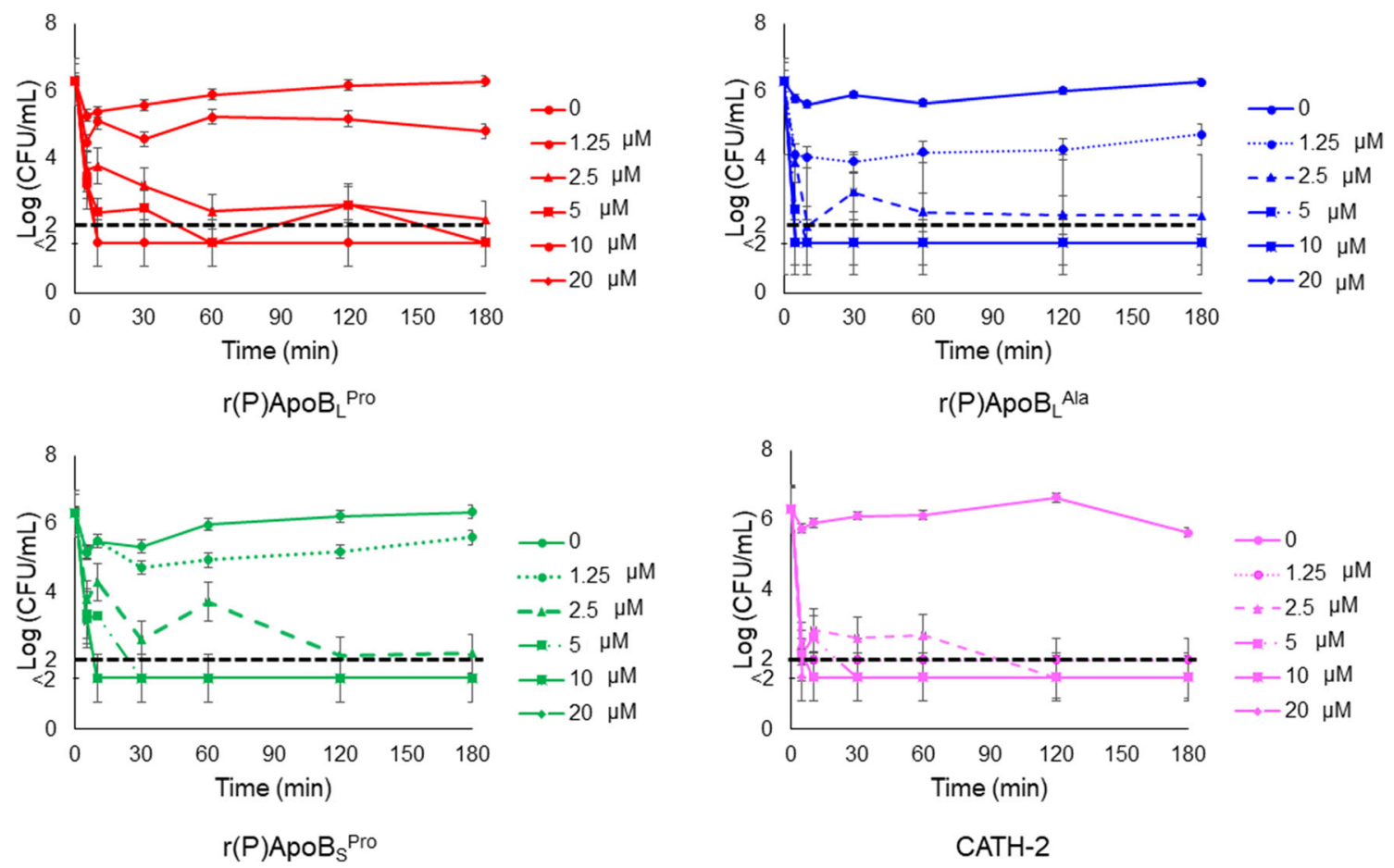

Fig. 2 Time killing curves obtained by incubating C. albicans ATCC 10231 with increasing concentrations of $\mathrm{r}(\mathrm{P}) \mathrm{ApoB}_{\mathrm{L}}{ }^{\mathrm{Pro}}, \mathrm{r}(\mathrm{P}) \mathrm{ApoB}_{\mathrm{L}}{ }^{\text {Ala }}$ or $r(\mathrm{P}) \mathrm{ApoB}_{\mathrm{S}}{ }^{\text {Pro }}$ peptides for different time intervals. Data represent the

C. albicans ATCC 10231 cells was mediated by membrane permeabilization. To support this finding, the effects of ApoBderived peptides on ATP leakage were also evaluated. To this purpose, C. albicans ATCC 10231 cells were treated with ApoB-derived peptides at concentrations corresponding to

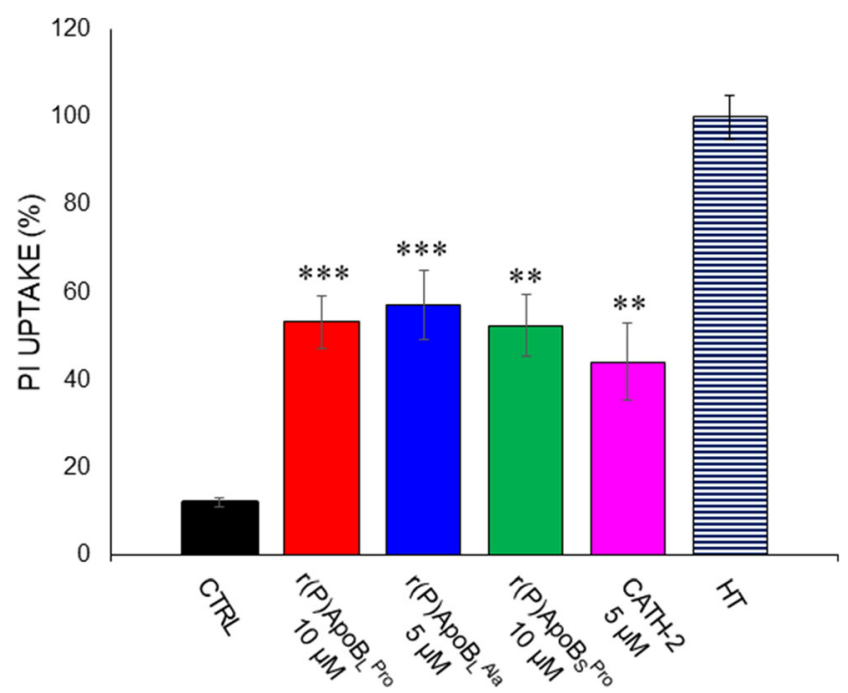

Fig. 3 Propidium iodide (PI) uptake into C. albicans ATCC 10231 cells upon treatment with $\mathrm{r}(\mathrm{P}) \mathrm{ApoB}_{\mathrm{L}}{ }^{\text {Pro }}, \mathrm{r}(\mathrm{P}) \mathrm{ApoB}_{\mathrm{L}}{ }^{\text {Ala }}$ or $\mathrm{r}(\mathrm{P}) \mathrm{ApoB}_{\mathrm{S}}{ }^{\text {Pro }}$. PI uptake was determined by a spectrofluorometric assay. Data represent the mean $( \pm$ SEM $)$ of at least three independent experiments, each one carried out with triplicate determinations. Significant differences were found to be $* * * * P<0.0001$ for treated versus control samples. CATH2 peptide and the heat-treated cells were used as positive controls

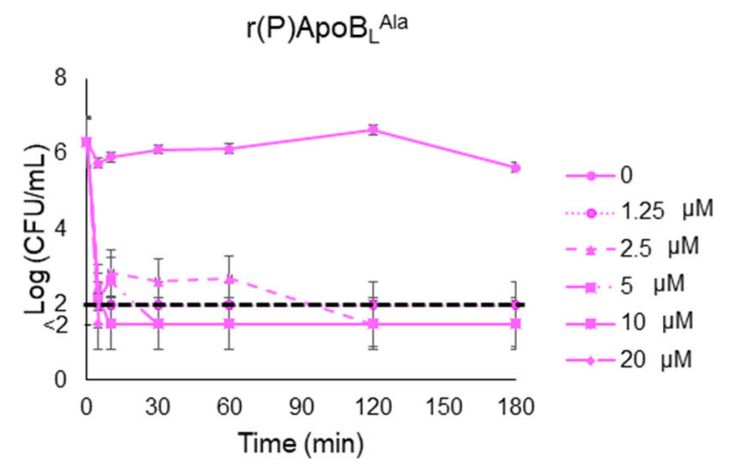

CATH-2

mean $( \pm$ SEM) of at least three independent experiments, each one carried out with triplicate determinations. Point values below the black dashed lines represent conditions in which 0 colonies were counted

MFC values for 10 and $60 \mathrm{~min}$ at $37^{\circ} \mathrm{C}$. Interestingly, it was observed that $\mathrm{r}(\mathrm{P}) \mathrm{ApoB}_{\mathrm{L}}{ }^{\text {Pro }}, \mathrm{r}(\mathrm{P}) \mathrm{ApoB}_{\mathrm{L}}{ }^{\mathrm{Ala}}$ and $\mathrm{r}(\mathrm{P}) \mathrm{ApoB}_{\mathrm{S}}{ }^{\text {Pro }}$ peptides induce ATP release from C. albicans ATCC 10231 cells after 10 min of incubation, with a slight increase after 60-min incubation only in the case of $\mathrm{r}(\mathrm{P}) \mathrm{ApoB}_{\mathrm{L}}{ }^{\text {Pro }}$ (Fig. 4). These results support propidium iodide data reported in Fig. 4 and indicate that membrane permeabilization occurs upon peptide treatment. Altogether, these findings allow us to hypothesize a fast interaction between ApoB-derived peptides and C. albicans ATCC 10231 cell membranes.

\section{Intracellular localization of ApoB-derived peptides in C. albicans ATCC 10231 cells}

In order to further investigate the mechanism of action of ApoB-derived peptides, live imaging analyses were carried out. To this purpose, C. albicans ATCC 10231 cells were treated with a fluorescent version of $\mathrm{r}(\mathrm{P}) \mathrm{ApoB}_{\mathrm{L}}{ }^{\text {Pro }}$ peptide, here named 5'-IAF-r(C)ApoB ${ }_{\mathrm{L}}^{\text {Pro }}$ (see the "Materials and methods" section for details) (Pane et al. 2018b; Pane et al. 2018a). The effects of 5'-IAF-r(C)ApoB ${ }_{\mathrm{L}}{ }^{\text {Pro }}$ on C. albicans ATCC 10231 cells were found to be identical to those of $\mathrm{r}(\mathrm{C}) \mathrm{ApoB}_{\mathrm{L}}{ }^{\text {Pro }}$, as reported in Supplementary Table S1 and in Supplementary Figure S3, thus indicating that the labelling procedure does not alter the peptide's mechanism of action.

C. albicans ATCC 10231 cells were treated with $10 \mu \mathrm{M} 5$ 'IAF-r(C)ApoB ${ }_{\mathrm{L}}{ }^{\text {Pro }}$ for $30 \mathrm{~min}$ in the presence of propidium 


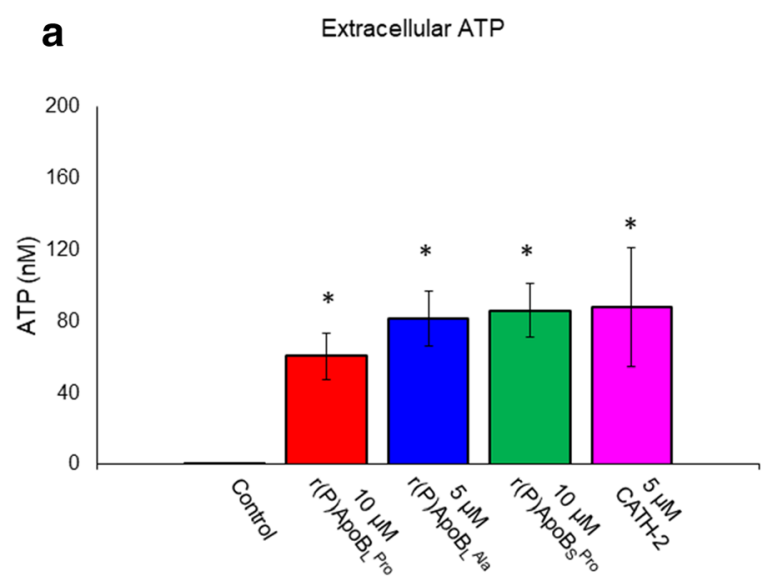

Fig. 4 ATP release from C. albicans ATCC 10231 cells upon treatment with $r(\mathrm{P}) \mathrm{ApoB}_{\mathrm{L}}{ }^{\text {Pro }}, \mathrm{r}(\mathrm{P}) \mathrm{ApoB}_{\mathrm{L}}{ }^{\text {Ala }}$ or $\mathrm{r}(\mathrm{P}) \mathrm{ApoB}_{\mathrm{S}}{ }^{\text {Pro }}$. ATP release was determined in the culture medium. Data represent the mean $( \pm \mathrm{SEM})$ of at least three independent experiments, each one carried out in duplicate,

iodide dye. Upon treatment, C. albicans ATCC 10231 cells were analysed by confocal laser scanning live imaging microscopy. Interestingly, fluorescently labelled peptide (green signal in Fig. 5) immediately appeared and localized at the fungal surface, with a progressive increase of fluorescent signal intensity over time (Fig. 5). Real tracking of 5'-IAF$\mathrm{r}(\mathrm{C}) \mathrm{ApoB}_{\mathrm{L}}{ }^{\text {Pro }}$ is provided as a supplementary movie. In agreement with this, a progressive uptake of propidium iodide in treated cells was observed over time (red signals associated to Candida cells). The phenomenon appears clearly evident even if red spots, probably due to aggregation of PI in culture b Extracellular ATP

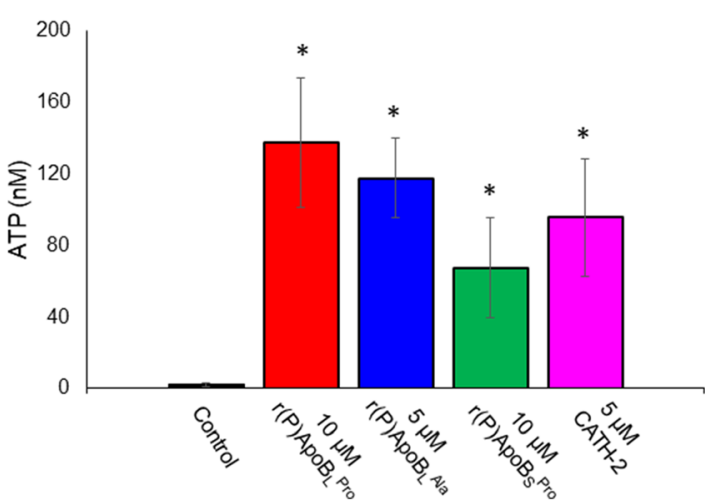

upon an incubation of 10 (A) or $60 \mathrm{~min}$ (B) with each peptide. Significant differences were found to be $* P<0.05$ for treated versus control samples. CATH-2 peptide was used as a positive control

medium, appear visible outside the cells. This suggests that peptide interaction with yeast membranes is immediately responsible for severe membrane damages (Fig. 5).

\section{Analysis of ApoB-derived peptides effects on A. niger N402}

The effects of ApoB-derived peptides were also tested on the filamentous fungus $A$. niger N402. To this purpose, metabolic activity of fungal spores in the absence or in the presence of increasing concentrations of peptides was evaluated by

$$
r(\mathrm{C}) \operatorname{ApoB}_{\mathrm{L}} \text { Pro }(10 \mu \mathrm{M})
$$

0
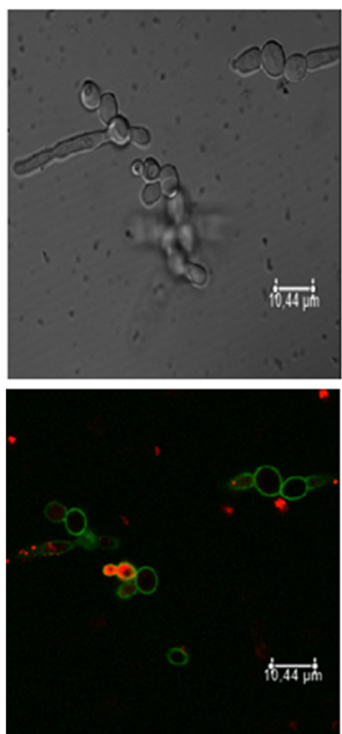

5
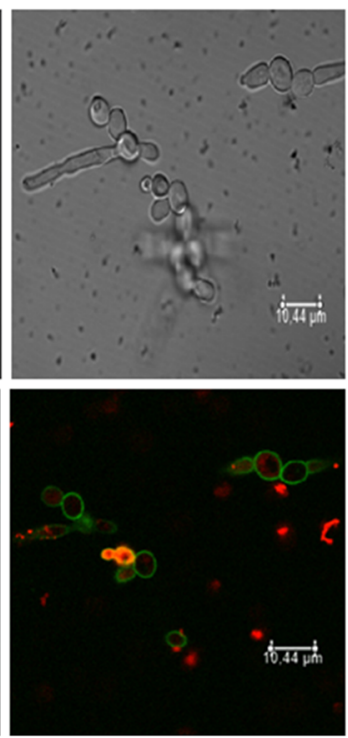

10
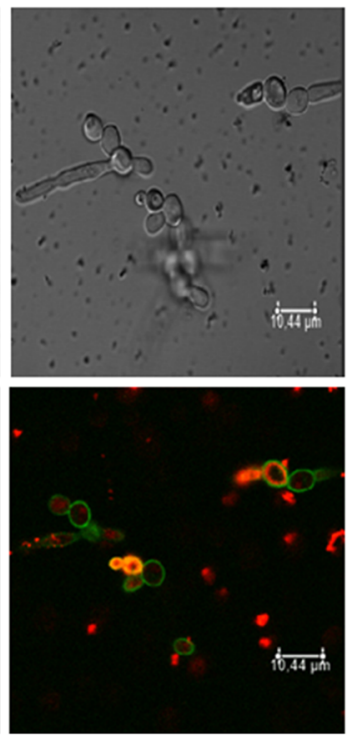

15
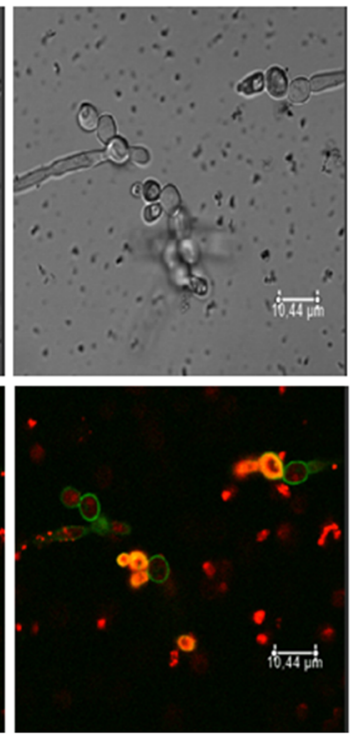

20 (min)
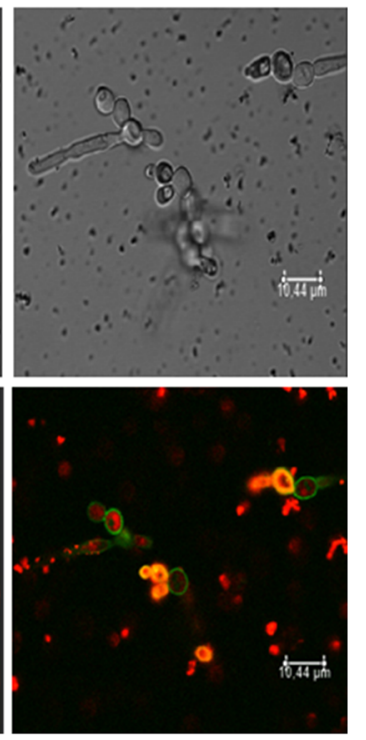

Fig. 5 Localization of 5'-IAF-r(C)ApoB ${ }_{\mathrm{L}}^{\text {Pro }}$ peptide (green signal) into C. albicans ATCC 10231 cells in the presence of propidium iodide (PI) dye (red signal) analysed by confocal laser scanning live imaging microscopy. Movies are provided as Supplementary material. Scale bar10 $\mu \mathrm{m}$ 
performing WST-1 assays. Interestingly, $\mathrm{r}(\mathrm{P}) \mathrm{ApoB}_{\mathrm{L}}{ }^{\text {Pro }}$, $\mathrm{r}(\mathrm{P}) \mathrm{ApoB}_{\mathrm{L}}{ }^{\mathrm{Ala}}, \mathrm{r}(\mathrm{P}) \mathrm{ApoB}_{\mathrm{S}}{ }^{\text {Pro }}$ and $\mathrm{CATH}-2$ peptides were found to reduce $A$. niger $\mathrm{N} 402$ spores' metabolic activity in a dose-dependent manner (Fig. 6). On the basis of the results of metabolic activity assays, $\mathrm{MFC}_{50}$ (minimal fungicidal concentrations) values were calculated for A. niger spores as the peptide concentration required to inhibit the metabolic activity of spores by $50 \%$. Data are reported in Supplementary Table S1. Filamentous fungi like A. niger reproduce asexually and form spores (or conidia) which easily spread in the environment. Spores are metabolically dormant and germinate under favourable environmental conditions (van Leeuwen et al. 2013). The switch from dormant spores to mycelium formation is associated with a defined sequence of events. During this process, fungi go through morphological changes associated with cell wall reorganization (Wendland 2001). For this reason, the effects of ApoB-derived peptides and CATH-2 were tested on swollen spores, initial hyphae and branched mycelium. To analyse the effects of peptides on swollen spores, spores were incubated for $6 \mathrm{~h}$ in minimal medium (MM). Following incubation, peptides were added at different concentrations and metabolic activity was analysed after a further 24-h incubation. It was found that ApoB-derived peptides, as well as $\mathrm{CATH}-2$, were able to significantly affect the metabolic activity of swollen spores (Fig. 6). The effects of the peptides on initial hyphae were also
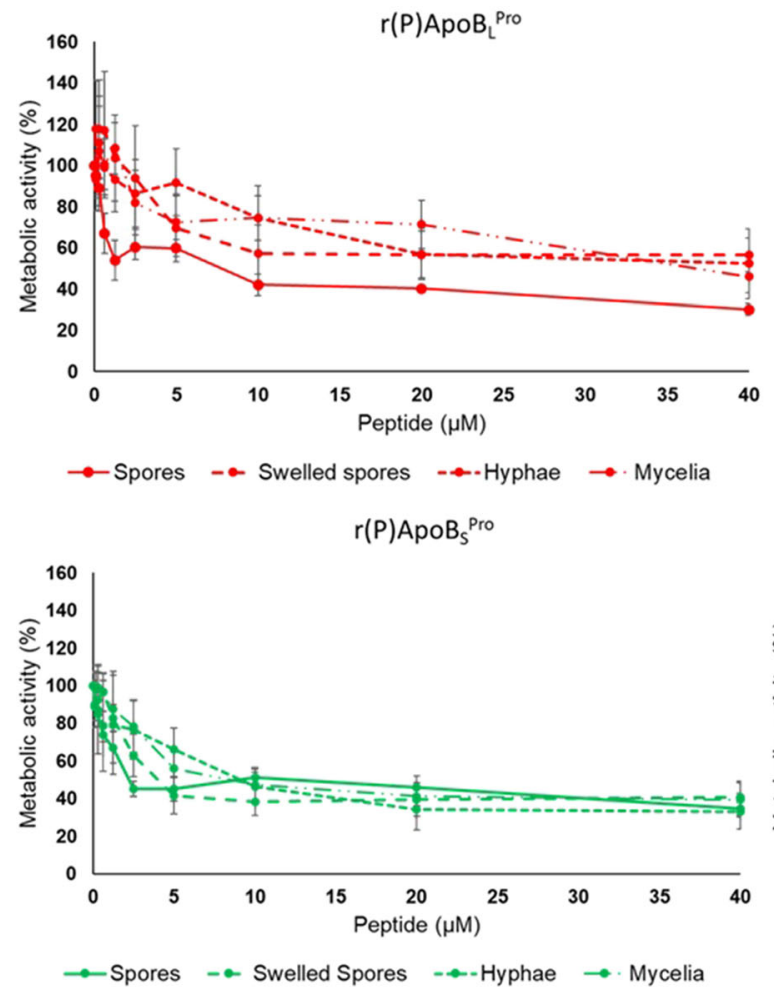

Fig. 6 Dose response curves reporting the effects of $\mathrm{r}(\mathrm{P}) \mathrm{ApoB}_{\mathrm{L}}{ }^{\text {Pro }}$, $\mathrm{r}(\mathrm{P}) \mathrm{ApoB}_{\mathrm{L}}{ }^{\mathrm{Ala}}, \mathrm{r}(\mathrm{P}) \mathrm{ApoB}_{\mathrm{S}}{ }^{\text {Pro }}$ and $\mathrm{CATH}-2$ used as a positive control, on the metabolic activity of $A$. niger N402 spores, swollen spores, initial hyphae and mycelium. Data represent the mean $( \pm$ SEM) of at least analysed. To this purpose, A. niger N402 spores were incubated for $16 \mathrm{~h}$, in order to allow germination and hyphal outgrowth. ApoB-derived HDPs were then added for a further $24 \mathrm{~h}$ and, at the end of the incubation, the WST-1 assay was performed to test the metabolic activity. Interestingly, all three ApoB-derived peptides were found to significantly affect metabolic activity of newly formed hyphae, while CATH-2 was effective only at the highest concentration tested (Fig. 6). When branched mycelium was analysed, $r(\mathrm{P}) \mathrm{ApoB}_{\mathrm{L}}{ }^{\mathrm{Ala}}$ and $\mathrm{r}(\mathrm{P}) \mathrm{ApoB}_{\mathrm{S}}{ }^{\text {Pro }}$ were found to be the most effective peptides, whereas $r(\mathrm{P}) \mathrm{ApoB}_{\mathrm{L}}{ }^{\text {Pro }}$ was found to be able to significantly reduce metabolic activity only at the highest concentration tested $(40 \mu \mathrm{M})$. CATH-2 was, instead, found to be ineffective (Fig. 6).

\section{Analysis of fluorescently labelled $\mathrm{r}(\mathrm{C}) \mathrm{ApoB}_{\mathrm{L}}{ }^{\text {Pro }}$ internalization into $A$. niger $\mathrm{N} 402$}

In order to further characterize the effects of ApoBderived peptides on $A$. niger $\mathrm{N} 402$, spores were incubated with $10-\mu \mathrm{M}$ fluorescently labelled $\mathrm{r}(\mathrm{C}) \mathrm{ApoB}_{\mathrm{L}}{ }^{\text {Pro }}$ for $24 \mathrm{~h}$ at $30^{\circ} \mathrm{C}$. Following incubation, confocal laser scanning microscopy analyses highlighted the ability of the 5'-IAF-r $(\mathrm{C}) \mathrm{ApoB}_{\mathrm{L}}{ }^{\text {Pro }}$ peptide to interact with swollen spores. Indeed, upon 16 -h incubation, 5'-IAF$\mathrm{r}(\mathrm{C}) \mathrm{ApoB}_{\mathrm{L}}{ }^{\text {Pro }}$ was found to accumulate into initial
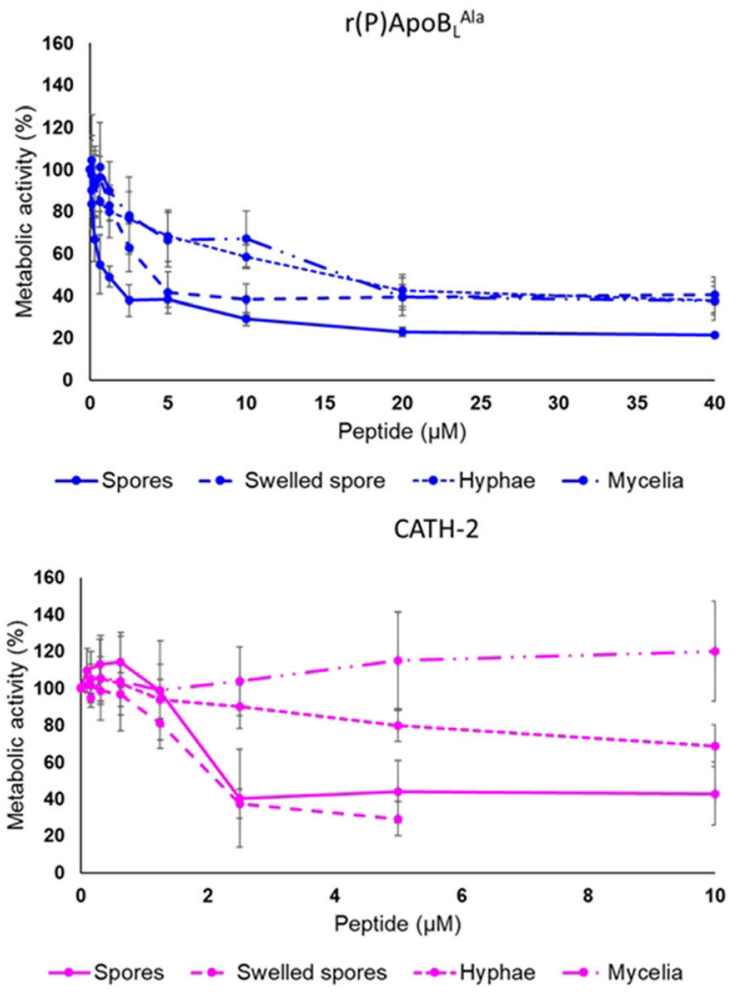

three independent experiments, each one carried out in triplicate. Statistical analyses revealed significant differences between treated and control samples $(* P<0.05$, ** for $P<0.01$, *** $P<0.001$ and $* * * * P<$ $0.0001)$ 
hyphae, with a consequent accumulation into branched mycelium upon 24-h incubation (Fig. 7).

\section{Discussion}

Yeasts and fungi are widespread organisms able to grow even in harsh conditions (Gulis and Bärlocher 2017; Bahafid et al. 2017). It is increasingly acknowledged that the intensive and increasing employment of antifungals in modern medicine, agriculture, and animal production is responsible for the fast development of resistance phenotypes (Kontoyiannis 2017). Along with antifungals misuse, the restricted number of effective antifungal agents represents an urgent issue (Verweij et al. 2016). The development of novel effective antifungal strategies based on yet unexplored molecules with alternative mechanisms of action is imperative. In this scenario, HDPs have attracted great attention because of their broad spectrum of activities and peculiar mechanism of action (Hancock and Lehrer 1998; Zasloff 2002; Brogden et al. 2003).

\section{ApoB-derived peptides exert fungicidal activity on C. albicans ATCC 10231}

Here, the antifungal activity of ApoB-derived peptides has been evaluated for the first time on $C$. albicans ATCC 10231 and on A. niger N402 filamentous fungus, selected as prototypes of fungal species responsible for human infections and food spoilage, respectively. Indeed, while Candida species are the most common pathogens responsible for infections in hospitalized patients characterized by a high mortality rate (Strollo et al. 2017), A. niger is a saprophytic and filamentous fungus generally able to adapt to several habitats and to produce mycotoxins, thus representing the main contaminant of several food samples, such as fruits, vegetables, cereals and nuts leading to their discoloration, rotting and decay (Morita and Nozawa 1985; Kim and Park 2012; Roemer and Krysan 2014; Cowen et al. 2015; Prakash et al. 2015; Kumar et al. 2017). Interestingly, $r(\mathrm{P}) \mathrm{ApoB}_{\mathrm{L}}{ }^{\mathrm{Pro}}, \mathrm{r}(\mathrm{P}) \mathrm{ApoB}_{\mathrm{L}}{ }^{\mathrm{Ala}}$ and $\mathrm{r}(\mathrm{P}) \mathrm{ApoB}_{\mathrm{S}}{ }^{\text {Pro }}$ peptides were found to be able to exert significant fungicidal activity when tested on $C$. albicans ATCC 10231. In particular, peptides were found to exploit their fungicidal action towards $C$. albicans within $10 \mathrm{~min}$ when tested at their MFC concentration values. Accordingly, membrane permeabilization assays highlighted an almost immediate interaction between ApoB-derived peptides and C. albicans cells, resulting in damage and permeabilization of membranes. In all cases, similar effects were observed for all three ApoB-derived peptides.

\section{ApoB-derived peptides immediately interact with C. albicans ATCC 10231 cell surface}

The production of fluorescently labelled $\mathrm{r}(\mathrm{C}) \mathrm{ApoB}_{\mathrm{L}}{ }^{\text {Pro }}$ peptide allowed us to analyse peptide mechanism of action by live imaging confocal laser scanning microscopy. Fluorescently

\section{$\mathrm{r}(\mathrm{C})$ ApoB $_{\mathrm{L}}$ Pro $5 \mu \mathrm{M}$}

0
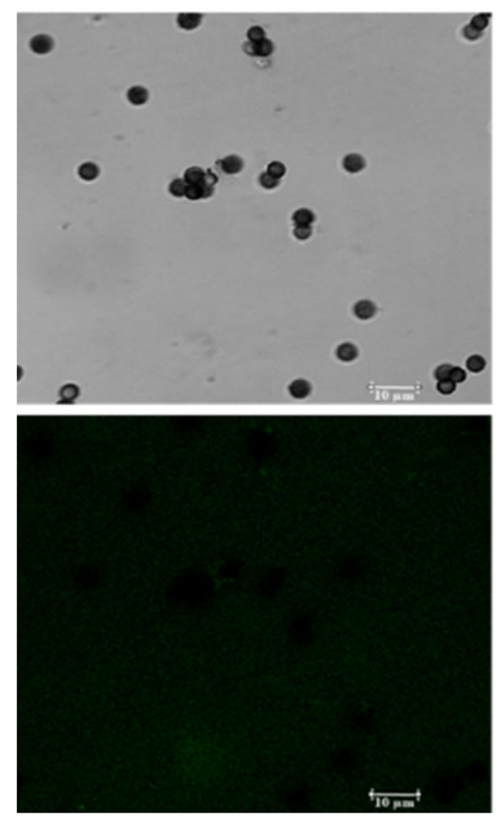

16
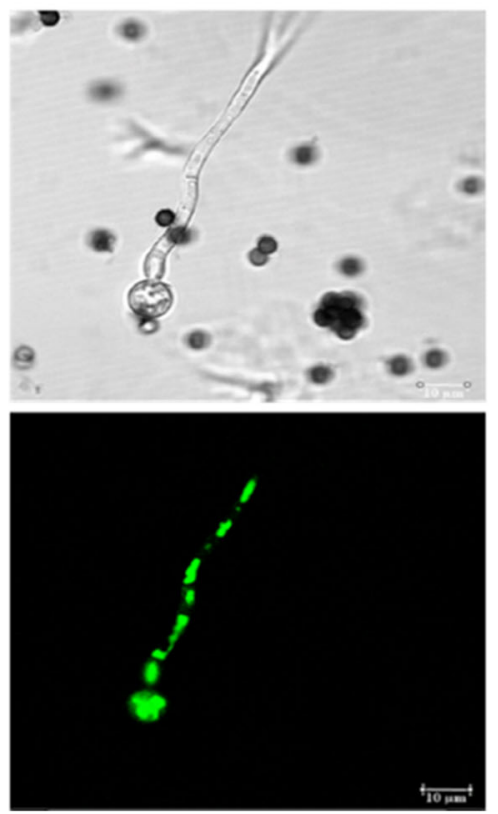

24
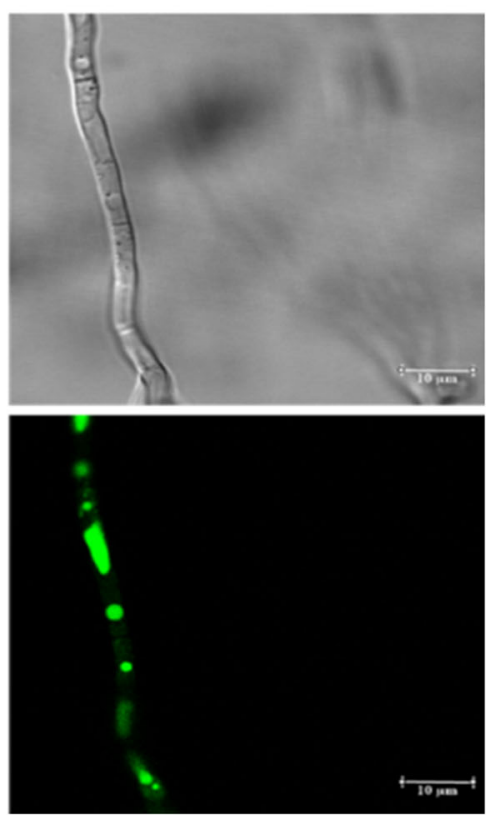

Fig. 7 Localization of 5'-IAF-r(C)ApoB ${ }_{\mathrm{L}}{ }^{\text {Pro }}$ peptide in A. niger $\mathrm{N} 402$ initial hyphae and branched mycelium. Images were acquired upon 0,16 and $24 \mathrm{~h}$ incubation of $A$. niger $\mathrm{N} 402$ with 5'-IAF-r(C)ApoB ${ }_{\mathrm{L}}{ }^{\text {Pro }}$ peptide. Scale bar $10 \mu \mathrm{m}$ 
labelled $\mathrm{r}(\mathrm{C}) \mathrm{ApoB}_{\mathrm{L}}{ }^{\text {Pro }}$ immediately localized on fungal cell surfaces, with an almost concomitant uptake of propidium iodide into the fungal cells. This phenomenon was found to progressively increase over time. Similar observations have been reported for different HDPs, such as astacidin 1 identified in hemocyanin of the freshwater crayfish Pacifastacus leniusculus (Choi and Lee 2014). This peptide was found to exert significant antifungal activity using a pore-forming mechanism on $C$. albicans cell membranes (Choi and Lee 2014). A similar mechanism of action has also been reported for HDPs CATH-2 and LL-37 (Ordonez et al. 2014). All these peptides have been reported to induce ATP leakage after 5min incubation when tested on $C$. albicans cells. In earlier studies, fluorescence microscopy analyses revealed that CATH-2 is able to immediately interact with $C$. albicans cells, while LL-37 requires about 3-min incubation prior to interaction with membranes (Ordonez et al. 2014).

\section{ApoB-derived peptides affect $A$. niger $\mathrm{N} 402$ metabolic activity}

Here, we also demonstrated that ApoB-derived peptides are able to affect the metabolic activity of A. niger N402 filamentous fungus. Interestingly, analyses on swollen spores, initial hyphae and branched mycelium highlighted that ApoBderived peptides are able to interact more efficiently with swollen spores and hyphae than with branched mycelium. These observations are in agreement with previous findings regarding the effects of Skh-AMP 1 peptide on Aspergillus fumigatus (Khani et al. 2020). Indeed, Skh-AMP 1 was found to be able to affect spores' survival rate, although at concentrations significantly higher than those required in the case of ApoB-derived peptides to exert significant effects. It has to be noticed that, differently from ApoB-derived peptides, SkhAMP 1 was found to act on Aspergillus hyphae membranes more efficiently than on spores (Khani et al. 2020). In the case of KK14 de novo synthesized peptide and its analogues, a significant inhibition of the growth of A. niger dormant spores was demonstrated, even if all the peptide analogues were found to lost their activity when tested on the germinating conidia (Thery et al. 2019b). However, these peptides are characterized by a different mechanism of action when compared to ApoB-derived HDPs, being able to permeabilize the cell wall of Fusarium culmorum (Thery et al. 2019b). In the case of ApoB-derived HDPs, no significant PI uptake and ATP leakage were detected upon incubation of $A$. niger incubation with peptides (data not shown). Hence, the obtained findings suggest that, even if ApoB-derived HDPs interact with the A. niger cell wall, no permeabilization is induced upon interaction. Consequently, peptide uptake might occur during swelling of the spores. Indeed, during this phase, water and nutrient uptake by spores is associated with a lower rigidity of the cell wall, an event that might favour peptide uptake with a consequent inhibition of fungal metabolic activity.

\section{ApoB-derived peptides affect different stages of growth of $A$. niger $\mathrm{N} 402$}

Our findings highlight the huge potentiality of ApoB-derived peptides, which are able to act at low concentrations and even on different fungal stages of growth, such as spores, generally recalcitrant to the treatment with conventional antifungal agents. Interestingly, confocal laser scanning microscopy analyses, performed using fluorescently labelled $\mathrm{r}(\mathrm{C}) \mathrm{ApoB}_{\mathrm{L}}{ }^{\text {Pro }}$ peptide, revealed peptide interaction with swollen spores and its subsequent accumulation into hyphae. In the case of PepBiotics CR173 and CR183, the ability to inactivate hyphae of A. fumigatus has been reported and correlated to a putative effect on mitochondria (van Eijk et al. 2020). In the literature, plant defensins, extracted from chopea seeds, have been reported to exert strong antifungal effects on Fusarium culmorum (Schmidt et al. 2019), although MFC values are higher than those here described for ApoB-derived peptides. In the case of chopea-thionin II, an initial interaction of the peptide with fungal cells was reported (Schmidt et al. 2019), with consequent membrane permeabilization and cell lysis or, as demonstrated here for ApoB-derived peptides, with subsequent internalization into fungal swollen spores or initial hyphae. Peptides isolated from Leuconostoc mesenteroides DU15 were, instead, found to be able to affect by $50 \%$ the growth of A. niger by causing significant morphological changes of branched mycelium, as evidenced by scanning electron microscopy analyses, and a reduction in the number of fungus cells (Muhialdin et al. 2015). Based on the obtained results, ApoB-derived peptides are able to exert strong effects on A. niger N402, and, even more importantly, they possess additional properties with respect to previously identified antifungal peptides, such as lower MFC values and the ability to affect different stages of fungal growth. Further experiments will be surely performed in the future to deepen on the molecular mechanism underlying the interesting properties demonstrated in the case of ApoB-derived peptides.

Altogether, the obtained findings indicate that ApoBderived peptides represent novel antifungal agents suitable for the future development of effective strategies to treat fungal infections generally recalcitrant to conventional therapeutic approaches, also considering that they have been previously demonstrated to be neither toxic nor haemolytic for murine and human eukaryotic cell lines (Gaglione et al. 2017).

Supplementary Information The online version contains supplementary material available at https://doi.org/10.1007/s00253-021-11114-3. 
Acknowledgements The authors would like to thank Richard Wubbolts and Esther van 't Veld from the Centre for Cell Imaging at Utrecht University for their help with the confocal imaging experiments.

Authors' contributions EDO, WRT, HdC and EJAV planned the research. $\mathrm{HPH}$, EJAV and AA supervised the project. EDO, RG, AC and VC executed the experiments. EDO, WRT, HdC, HPH and EJAV analysed the data. RG, $\mathrm{AC}, \mathrm{VC}$ and $\mathrm{EN}$ recombinantly produced peptides and fluorescently labelled $\mathrm{r}(\mathrm{C}) \mathrm{ApoB}_{\mathrm{L}}{ }^{\text {Pro }}$ peptide. EDO and AA wrote the manuscript. All authors discussed the results and commented on the manuscript.

Funding Open Access funding provided by Università degli Studi di Napoli Federico II.

Data availability All data generated or analysed during this study are included in this published article and its supplementary information files.

\section{Declarations}

Conflict of interest The authors declare no conflict of interest.

Ethics statement This article does not contain any studies with human participants or animals performed by any of the authors.

Open Access This article is licensed under a Creative Commons Attribution 4.0 International License, which permits use, sharing, adaptation, distribution and reproduction in any medium or format, as long as you give appropriate credit to the original author(s) and the source, provide a link to the Creative Commons licence, and indicate if changes were made. The images or other third party material in this article are included in the article's Creative Commons licence, unless indicated otherwise in a credit line to the material. If material is not included in the article's Creative Commons licence and your intended use is not permitted by statutory regulation or exceeds the permitted use, you will need to obtain permission directly from the copyright holder. To view a copy of this licence, visit http://creativecommons.org/licenses/by/4.0/.

\section{References}

Alastruey-Izquierdo A, Mellado E, Peláez T, Pemán J, Zapico S, Alvarez M, Rodríguez-Tudela JL, Cuenca-Estrella M (2013) Populationbased survey of filamentous fungi and antifungal resistance in Spain (FILPOP study). Antimicrob Agents Chemother 57:3380 3387. https://doi.org/10.1128/AAC.00383-13

Anaissie EJ, Stratton SL, Dignani MC, Summerbell RC, Rex JH, Monson TP, Spencer T, Kasai M, Francesconi A, Walsh TJ (2002) Pathogenic Aspergillus species recovered from a Hospital Water System: a 3-year prospective study. Clin Infect Dis 34:780-789. https://doi.org/10.1086/338958

Aoki W, Ueda M (2013) Characterization of antimicrobial peptides toward the development of novel antibiotics. Pharmaceuticals 6:1055-1081

Badiee P, Hashemizadeh Z (2014) Opportunistic invasive fungal infections: Diagnosis \& clinical management. Indian J Med Res 139:195-204

Bahafid W, Joutey NT, Asri M, Sayel H, Tirry N, El Ghachtouli N (2017) Yeast biomass: an alternative for bioremediation of heavy metals. In: Yeast - Industrial Applications. InTech

Bellmann R, Smuszkiewicz P (2017) Pharmacokinetics of antifungal drugs: practical implications for optimized treatment of patients. Infection 45:737-779. https://doi.org/10.1007/s15010-017-1042-z

Bennett JE, Dolin R, Blaser MJ (2014) Mandell, Douglas, and Bennett's Principles and Practice of Infectious Diseases. Elsevier Inc.
Bondaryk M, Staniszewska M, Zielińska P, Urbańczyk-Lipkowska Z (2017) Natural antimicrobial peptides as inspiration for design of a new generation antifungal compounds. J Fungi 3

Bowman JC, Hicks PS, Kurtz MB, Rosen H, Schmatz DM, Liberator PA, Douglas CM (2002) The antifungal echinocandin caspofungin acetate kills growing cells of Aspergillus fumigatus in vitro. Antimicrob Agents Chemother 46:3001-3012. https://doi.org/10.1128/aac.46.9. 3001-3012.2002

Brogden KA, Ackermann M, McCray PB, Tack BF (2003) Antimicrobial peptides in animals and their role in host defences. Int J Antimicrob Agents 22:465-478. https://doi.org/ 10.1016/s0924-8579(03)00180-8

Brown GD, Denning DW, Gow NAR, Levitz SM, Netea MG, White TC (2012) Hidden killers: human fungal infections. Sci Transl Med 4: $165 \mathrm{rv} 13$

Choi H, Lee DG (2014) Antifungal activity and pore-forming mechanism of astacidin 1 against Candida albicans. Biochimie 105:58-63. https://doi.org/10.1016/j.biochi.2014.06.014

Ciociola T, Giovati L, Conti S, Walter Magliani CS\& LP (2016) Natural and synthetic peptides with antifungal activity. Future Med Chem

Cowen LE, Sanglard D, Howard SJ, Rogers PD, Perlin DS (2015) Mechanisms of antifungal drug resistance. Cold Spring Harb Perspect Med 5:1-22. https://doi.org/10.1101/cshperspect.a019752

Cuperus T, Coorens M, van Dijk A, Haagsman HP (2013) Avian host defense peptides. Dev Comp Immunol 41:352-369. https://doi.org/ 10.1016/j.dci.2013.04.019

De Vries RP, Burgers K, Van De Vondervoort PJI, Frisvad JC, Samson RA, Visser J (2004) A new black Aspergillus species, A. vadensis, is a promising host for homologous and heterologous protein production. Appl Environ Microbiol 70:3954-3959. https://doi.org/10. 1128/AEM.70.7.3954-3959.2004

Essig A, Hofmann D, Münch D, Gayathri S, Künzler M, Kallio PT, Sahl HG, Wider G, Schneider T, Aebi M (2014) Copsin, a novel peptide-based fungal antibiotic interfering with the peptidoglycan synthesis. J Biol Chem 289:34953-34964. https://doi.org/10.1074/jbc.M114.599878

Fisher MC, Hawkins NJ, Sanglard D, Gurr SJ (2018a) Worldwide emergence of resistance to antifungal drugs challenges human health and food security. Science (80-.) 360:739-742

Fisher MC, Hawkins NJ, Sanglard D, Gurr SJ (2018b) Worldwide emergence of resistance to antifungal drugs challenges human health and food security. Science (80-. ) 360:739-742

Gaglione R, Dell'Olmo E, Bosso A, Chino M, Pane K, Ascione F, Itri F, Caserta S, Amoresano A, Lombardi A, Haagsman HP, Piccoli R, Pizzo E, Veldhuizen EJA, Notomista E, Arciello A (2017) Novel human bioactive peptides identified in apolipoprotein $\mathrm{B}$ : evaluation of their therapeutic potential. Biochem Pharmacol 130:34-50. https://doi.org/10.1016/j.bcp.2017.01.009

Gaglione R, Cesaro A, Dell'Olmo E, Della Ventura B, Casillo A, Di Girolamo R, Velotta R, Notomista E, Veldhuizen EJA, Corsaro MM, De Rosa C, Arciello A (2019a) Effects of human antimicrobial cryptides identified in apolipoprotein B depend on specific features of bacterial strains. Sci Rep 9:9. https://doi.org/10.1038/s41598-019-43063-3

Gaglione R, Pane K, Dell'Olmo E, Cafaro V, Pizzo E, Olivieri G, Notomista E, Arciello A (2019b) Cost-effective production of recombinant peptides in Escherichia coli. New Biotechnol 51:39-48. https://doi.org/10.1016/j.nbt.2019.02.004

Gaglione R, Cesaro A, Dell'olmo E, Di Girolamo R, Tartaglione L, Pizzo E, Arciello A (2020) Cryptides identified in human apolipoprotein b as new weapons to fight antibiotic resistance in cystic fibrosis disease. Int J Mol Sci 21:21. https://doi.org/10.3390/ijms21062049

Gulis V, Bärlocher F (2017) Fungi: biomass, production, and community structure. In: Methods in Stream Ecology: Third Edition. Elsevier Inc., pp 177-192

Hancock REW, Lehrer R (1998) Cationic peptides: a new source of antibiotics. Trends Biotechnol 16:82-88 
Jang WS, Bajwa JS, Sun JN, Edgerton M (2010) Salivary histatin 5 internalization by translocation, but not endocytosis, is required for fungicidal activity in Candida albicans. Mol Microbiol 77:354-370. https://doi.org/10.1111/j.1365-2958.2010.07210.x

Khani S, Seyedjavadi SS, Hosseini HM, Goudarzi M, Valadbeigi S, Khatami S, Ajdary S, Eslamifar A, Amani J, Imani Fooladi AA, Razzaghi-Abyaneh M (2020) Effects of the antifungal peptide Skh-AMP1 derived from Satureja khuzistanica on cell membrane permeability, ROS production, and cell morphology of conidia and hyphae of Aspergillus fumigatus. Peptides. 123:170195. https://doi. org/10.1016/j.peptides.2019.170195

Kim E, Park IK (2012) Fumigant antifungal activity of Myrtaceae essential oils and constituents from Leptospermum petersonii against three Aspergillus species. Molecules 17:10459-10469. https://doi. org $/ 10.3390 /$ molecules 170910459

Kontoyiannis DP (2017) Antifungal resistance: an emerging reality and a global challenge. J Infect Dis 216:S431-S435. https://doi.org/10. 1093/infdis/jix179

Kościuczuk EM, Lisowski P, Jarczak J, Strzałkowska N, Jóźwik A, Horbańczuk J, Krzyżewski J, Zwierzchowski L, Bagnicka E (2012) Cathelicidins: family of antimicrobial peptides. A review Mol Biol Rep 39:10957-10970

Kumar P, Mishra S, Kumar A, Kumar S, Prasad CS (2017) In vivo and in vitro control activity of plant essential oils against three strains of Aspergillus niger. Environ Sci Pollut Res 24:21948-21959. https:// doi.org/10.1007/s1 1356-017-9730-x

Lupetti A, Van Dissel JT, Brouwer CPJM, Nibbering PH (2008) Human antimicrobial peptides' antifungal activity against Aspergillus fumigatus. Eur J Clin Microbiol Infect Dis 27:1125-1129. https:// doi.org/10.1007/s10096-008-0553-z

Mookherjee N, Anderson MA, Haagsman HP, Davidson DJ (2020) Antimicrobial host defence peptides: functions and clinical potential. Nat Rev Drug Discov 19:311-332

Morita T, Nozawa Y (1985) Effects of antifungal agents on ergosterol biosynthesis in Candida albicans and Trichophyton mentagrophytes: differential inhibitory sites of naphthiomate and miconazole. J Invest Dermatol 85:434-437. https://doi.org/10. 1111/1523-1747.ep12277141

Muhialdin BJ, Hassan Z, Abu Bakar F, Algboory HL, Saari N (2015) Novel antifungal peptides produced by Leuconostoc mesenteroides DU15 effectively inhibit growth of Aspergillus niger. J Food Sci 80: M1026-M1030. https://doi.org/10.1111/1750-3841.12844

Neelabh, Singh K, Rani J (2016) Sequential and structural aspects of antifungal peptides from animals, bacteria and fungi based on bioinformatics tools. Probiotics Antimicrob Proteins 8:85-101

Ordonez SR, Amarullah IH, Wubbolts RW, Veldhuizen EJA, Haagsman HP (2014) Fungicidal mechanisms of cathelicidins LL-37 and CATH-2 revealed by live-cell imaging. Antimicrob Agents Chemother 58:2240-2248. https://doi.org/10.1128/AAC.01670-13

Pane K, Cafaro V, Avitabile A, Torres MDT, Vollaro A, De Gregorio E, Catania MR, Di Maro A, Bosso A, Gallo G, Zanfardino A, Varcamonti M, Pizzo E, Di Donato A, Lu TK, De La FuenteNunez C, Notomista E (2018a) Identification of novel cryptic multifunctional antimicrobial peptides from the human stomach enabled by a computational-experimental platform. ACS Synth Biol 7: 2105-2115. https://doi.org/10.1021/acssynbio.8b00084

Pane K, Verrillo M, Avitabile A, Pizzo E, Varcamonti M, Zanfardino A, Di Maro A, Rega C, Amoresano A, Izzo V, Di Donato A, Cafaro V, Notomista E (2018b) Chemical cleavage of an Asp-Cys sequence allows efficient production of recombinant peptides with an Nterminal cysteine residue. Bioconjug Chem 29:1373-1383. https:// doi.org/10.1021/acs.bioconjchem.8b00083

Prakash B, Kedia A, Mishra PK, Dubey NK (2015) Plant essential oils as food preservatives to control moulds, mycotoxin contamination and oxidative deterioration of agri-food commodities - potentials and challenges. Food Control 47:381-391

Roemer T, Krysan DJ (2014) Antifungal drug development: challenges, unmet clinical needs, and new approaches. Cold Spring Harb Perspect Med 4

Sanglard D (2016) Emerging threats in antifungal-resistant fungal pathogens. Front Med 3

Schmidt M, Arendt EK, Thery TLC (2019) Isolation and characterisation of the antifungal activity of the cowpea defensin Cp-thionin II. Food Microbiol 82:504-514. https://doi.org/10.1016/j.fm.2019.03.021

Schmiedel Y, Zimmerli S (2016) Common invasive fungal diseases: an overview of invasive candidiasis, aspergillosis, cryptococcosis, and Pneumocystis pneumonia. Swiss Med Wkly 146:w14281

Sobel JD (2007) Vulvovaginal candidiasis. Lancet 369:1961-1971. https://doi.org/10.1016/S0140-6736(07)60917-9

Staab JF (1999) Adhesive and mammalian transglutaminase substrate properties of Candida albicans Hwp1. Science (80- ) 283:15351538. https://doi.org/10.1126/science.283.5407.1535

Stone WL, Qui M, Smith M (2003) Lipopolysaccharide enhances the cytotoxicity of 2-chloroethyl ethyl sulfide. BMC Cell Biol 4:1. https://doi.org/10.1186/1471-2121-4-1

Strollo S, Lionakis MS, Adjemian J, Steiner CA, Prevots DR (2017) Epidemiology of hospitalizations associated with invasive candidiasis, United States, 2002-2012. Emerg Infect Dis 23:7-13. https:// doi.org/10.3201/eid2301.161198

Sun E, Belanger CR, Haney EF, Hancock REW (2018) Host defense (antimicrobial) peptides. In: Peptide Applications in Biomedicine, Biotechnology and Bioengineering. Elsevier Inc., pp 253-285

Thery T, Lynch KM, Arendt EK (2019a) Natural antifungal peptides/ proteins as model for novel food preservatives. Compr Rev Food Sci Food Saf 18:1327-1360

Thery T, Shwaiki LN, O'Callaghan YC, O’Brien NM, Arendt EK (2019b) Antifungal activity of a de novo synthetic peptide and derivatives against fungal food contaminants. J Pept Sci 25:e3137. https://doi.org/10.1002/psc.3137

Thevissen K, Kristensen HH, Thomma BPHJ, Cammue BPA, Francois IEJA (2007) Therapeutic potential of antifungal plant and insect defensins. Drug Discov Today 12:966-971

Van Dijk A, Veldhuizen EJA, Kalkhove SIC, Tjeerdsma-Van Bokhoven JLM, Romijn RA, Haagsman HP (2007) The $\beta$-defensin gallinacin6 is expressed in the chicken digestive tract and has antimicrobial activity against food-borne pathogens. Antimicrob Agents Chemother 51:912-922. https://doi.org/10.1128/AAC.00568-06

van Eijk M, Boerefijn S, Cen L, Rosa M, Morren MJH, van der Ent CK, Kraak B, Dijksterhuis J, Valdes ID (2020) Haagsman HP, de Cock $\mathrm{H}$ Cathelicidin-inspired antimicrobial peptides as novel antifungal compounds. Med Mycol 58:1073-1084. https://doi.org/10.1093/ MMY/MYAA014

van Leeuwen MR, Krijgsheld P, Bleichrodt R, Menke H, Stam H, Stark J, Wösten HAB, Dijksterhuis J (2013) Germination of conidia of Aspergillus niger is accompanied by major changes in RNA profiles. Stud Mycol 74:59-70. https://doi.org/10.3114/sim0009

Verweij PE, Chowdhary A, Melchers WJG, Meis JF (2016) Azole resistance in Aspergillus fumigatus: can we retain the clinical use of mold-active antifungal azoles? Clin Infect Dis 62:362-368. https:// doi.org/10.1093/cid/civ885

Wendland J (2001) Comparison of morphogenetic networks of filamentous fungi and yeast. Fungal Genet Biol 34:63-82

Zasloff M (2002) Antimicrobial peptides of multicellular organisms. Nature 415:389-395

Publisher's note Springer Nature remains neutral with regard to jurisdictional claims in published maps and institutional affiliations. 